August 2016

\title{
The Cost of Inter-Ethnic Conflicts in Ghana's Northern Region: The Case of the Nawuri-Gonja Conflicts
}

\author{
Emmanuel Debrah \\ University of Ghana, edebrah@ug.edu.gh \\ Seidu Alidu \\ University of Ghana, seidualidu@gmail.com \\ Isaac Owusu-Mensah \\ University of Ghana, iomensah@ug.edu.gh
}

Follow this and additional works at: https://digitalcommons.usf.edu/jacaps

Part of the Comparative Politics Commons, and the Other Social and Behavioral Sciences Commons

\footnotetext{
Recommended Citation

Debrah, Emmanuel; Alidu, Seidu; and Owusu-Mensah, Isaac (2016) "The Cost of Inter-Ethnic Conflicts in Ghana's Northern Region: The Case of the Nawuri-Gonja Conflicts," Journal of African Conflicts and Peace Studies: Vol. 3: Iss. 1, . DOI: http://dx.doi.org/10.5038/2325-484X.3.1.1068

Available at: https://digitalcommons.usf.edu/jacaps/vol3/iss1/2

This Article is brought to you for free and open access by the Open Access Journals at Digital Commons @ University of South Florida. It has been accepted for inclusion in Journal of African Conflicts and Peace Studies by an authorized editor of Digital Commons @ University of South Florida. For more information, please contact digitalcommons@usf.edu.
} 


\section{The Cost of Inter-Ethnic Conflicts in Ghana's Northern Region: The Case of the Nawuri-Gonja Conflicts}

\section{Cover Page Footnote}

Dr Emmanuel Debrah is Senior lecturer and Chair of Department of Political Science, university of Ghana. His recent articles are found in African Studies Review, Peace Studies Journal and Africa Today Dr Seidu M. Alidu is Lecturer, Department of Political Science 


\section{Introduction}

Since the end of the Cold War, Africa has attracted the attention of the international community for its violent conflicts. For instance, ethno-political and chieftaincy conflicts in Africa have dominated the international media and occupied priority attention on the agenda of intergovernmental, regional and sub-regional organizations. The conflicts have also featured prominently in the governance discourses of civil society groups, policymakers and academics because of their debilitating to the already impoverished African society. More worrying to governments and international donors is the emerging phenomenon where conflict societies are gradually becoming the sanctuaries for terrorist groups' activities such as Boko Haram, AlShabaab, Al-Qa'ida in the Maghreb region, among others. While the Liberian, Sierra Leonean and Ivoirian civil wars as well as Boko Haram activities in Nigeria and political turmoil in Guinea and Mali have been highlighted in many scholarly studies, inter-ethnic violent-conflicts in Ghana such as the Nawuri- Gonja conflicts has not been given adequate attention in the literature of post-democratization African politics. Yet, in recent years, the Northern Region has been the scene of sporadic ethnic conflicts with high recurrence rate. For instance, of the estimated over one hundred chieftaincy and ethnic disputes across the country, the Northern Region alone accounts for 70 percent of them (Tonah 2012; Seini and Tsikata 2004). Even prior to the return to democratic rule in 1992, several inter-ethnic conflicts have been fought in the Northern Region such as the 1984, 1986 and 1989 Kokomba-Bimoba wars, which claimed over 97 deaths.

By 2010, almost every Traditional Council Area in the Northern Region had been soaked in chieftaincy and ethnic upheavals (Jonsson 2007; Lund 2003; Kaye and Beland 2009). Small ethnic groups would construct alliance with others to fight dominant ethnic groups regarded as 'overlords'. For instance, in 1992 Gonja-Vagla, Konkomba-Nanumba, Mamprusi-Kusasi, and Kokomba formed a war pact and fough against Gonjas, which lasted several months, thereby destabilizing the peace of the area (Pul, 2003). The 'alliance war' did not end completed when Kokomba and Mossi war broke out in 1993. In the year that followed, 1994, a more fierce interethnic battle unprecedented engulfed the neighbouring groups. The Konkomba-Nanumba war was sparked on 31 January 1994 in the market of the small town of Nakpayili over the price of a 
guinea fowl. Initially, the clash occurred between two men: a Konkomba and a Nanumba, 'which eventually led to the killing of the Nanumba man' (Assefa 2001: 165). By the close of 1995, the Guinea Fowl War had claimed over 2,000 deaths, 230,000 displaced and destruction of over 500 villages (Tonah 2012; Brukum 2001; Awodoba 2009; Mahama 2003). Similar violence occurred in Bawku in the Upper East Region between Mamprusis and Kusasis in 2001 and 2002 in connection with local elections and the appointment of a mayor (District Chief Executive) (Lund, 2003).

Give that conflict is a recurrent phenomenon in the Northern Region and the fact that Nawuri and Gonja are two powerful ethnic groups in the area, and fought one of the brutal and ceaseless ethnic wars, which led to the lost of several hundreds of lives and devastated a region that is underdeveloped in relations to other regions with only 2.5 million people and a country that has a population of a little over 24 million (Ghana Statistical Service, 2010), it may be worthwhile to examine the Nawuri-Gonja conflicts. More striking is that the number of scholarly analysis of ethnic conflicts in Northern Regions has focused more on Dagomba chieftaincy conflicts (Staniland, 1975; Nugent and Lentz 2000), Fulani nomadic activities (Tonah 2007), KokombaDagomba war (Pul, 2003; Skalik 1986), Kusasis and Mamprusis conflict (Lund, 2003) to the virtual neglect of the Nawuri and Gonja conflict. Where sporadic reference was made in some scholarly analysis of Nawuri-Gonja conflicts such as Brukum (1999), Mahama (2003) and Mbowura (2012), anecdotal rather than empirical discussions blurred our understanding of the dynamics, social and economic consequences of the ethnic violent conflicts. Therefore, this study, which examines popular attitudes and perceptions as well as eye-witness insights in the conflicts offer the most appropriate approach to understanding the causes, processes, and consequences of the Nawuri-Gonja conflicts as well as lessons to be learnt from them. The article is organized into five sections. Section one examines the theoretical imperatives; section two, the methods; section three demographics of the Northern Region; section analyses the conflicts and their ramifications and section five considers the lessons. 


\section{The Cultural-Ethnic-Conflict Framework}

Conflicts that have occurred in Ghana's Northern Region are complex and have largely revolved around issues of ethnic identity, group history and rights, which are intimately connected with social and political status as well as economic opportunities. Therefore, it may be necessary to situate the discussion within group history, tradition, customs and culture as these interact with modern conception of poverty, land rights and marginalization that have largely constituted the basis for the eruption of ethnic conflicts in Ghana, which this study interrogates some of them. Anthropologists and Sociologists have explained the rise of ethnic nation-states, the oppression of ethnic groups by others, and why ethnic groups fight over territories. They have deployed conceptual tools such as primordial and constructivist perspectives to explain ethnic identities (Berger and Luckmann 1967). The primordial school posits that ethnic identity is inherent in human fabric. In other words man's desire to identify with groups whose characteristics they possess is a spontaneous act (Scott 1990). There is the tendency for people to act in opposition to other ethnic groups thereby leading to the rejection of "aliens". Also, the desire by groups to assert their authority over others often results in the oppression of weaker ethnic groups by more powerful ones, xenophobia behaviours and violent "ethnic cleansing," (the removal of one ethnic group from the land by another group who wants exclusive rights to the same land). According to Scott $(1990,167)$ "the concept of "primordial sentiments" is essential for understanding the affective dimension of ethnicity', particularly regarding the kinds of emotions they have experienced and the thoughts around which the emotions centered (Kaye, \& Béland, 2009). However, some scholars think that primordial sentiments must be tied to the circumstances under which they occur (Scott, 1990; Kaye, \& Béland, 2009). Also, whenever ethnicity, is defined as the human need to belong to a specific group of people, institutions or ideology, it is often expressed as a voluntary allegiance, which makes it easy for manipulation by individuals to advance their interests relative to opportunities available within the environment (Turton, 1997). The primordial school has encouraged ethnocentrism across the globe where strong ethnic groups have pressed for separation and "ethnic entrepreneurs" have manipulated ethnic identity to instigate class conflicts. For instance, politicians of dominant ethnic groups in Liberia, Sieraa Leone, Bosnai, Croatia and Serbia, among others, executed their political agendas by appealing 
to ethnic identity, which led to the atrocious decimation of minority populations in those countries (Crawford, 2007).

By contrast, the "constructivist" model asserts that ethnic identity is malleable and dynamic rather than innate and unchanging. Thus, ethnicity is the creation of social, political, and historical forces, rather than being a change of individual identities over time due to changing in the social context. Advocates of this model have opined that people exhibit different identities in different settings, which are subject to periodic disappearance, return and reinventions (Muller 2008). For instance, an ethnic group that is oppressed on the basis of say ethnic identity, may either assimilate into another dominant group, thereby taking a new identify upon its own one, or intensify group solidarity and identity in order to resist and struggle for equal rights or political control for the benefit of its group (Fearon and Laitin 2000). In contemporary complex governance systems where immigrants and refugees seek for integration into existing ethnic arrangements of other nation-states through legal processes, group autonomy is now a relic.

The constructivist theorists have explained that the primordialists' claim of possible "accumulated hatreds" among dominant ethnic groups is not tenable in contemporary societies where different ethnic groups coexist peacefully (Kaye, \& Béland, 2009). The constructivists have argued that ethnicity has assumed new dimensions, especially in complex modern societies such as the United States of America and Western Europe where these societies have become multi-ethnic and culturally diverse. Within these societies, for instance, ethnic groups that once lived in opposition to each other have smoked the peace pipe and buried their distinct loyalties under a multi-ethnic nation. As a result, ethnic tensions have abated because the question of national identity is no longer tied to the belief that the nation is the "homeland" of one specific ethnic group (Crawford, 2007).

Despite these, however, Horowitz (1998) has noted that polarized views of ethnicity either the primordial or circumstantial architecture, perpetuates the cycle of definitional casuistry among theorists, which have unnecessarily stalemated the advancement of cumulative knowledge on ethnicity. 
Hence, Scott $(1990,163)$ has provided a synthetic approach where 'we no longer need to dichotomize persistent and fluctuating ethnicity; rather, we can now place them along a continuum of degree of ethnic solidarity'. For instance, the specific cases of conflict and their consequences in the Northern Region of Ghana justify the examination of processes of ethnopoliticization by focusing on degrees of ethnic-based cohesion. It is believed that this approach allows scholars to remain attentive to both the variables and salient characteristics of ethnicity that emerge under particular circumstances. Some scholars have further argued that the 'content of any particular ethnicity is historically contingent' (Lentz 2006, 3). Therefore, the origins of particular ethnic categories are inter-subjective and potentially imagined. These subjective perceptions and past experiences tend to interact with 'political memory' to produce new categories of identification. According to Rothchild (1997), these new socially constructed' categories form the 'basis of a consciousness that can prove to be destructive.

Other students of ethnic conflict have examined similar ways in which ethnic affiliations are politicized (Bakwesegha 2004; Gurr and Pitsch 2003). According to Gurr (1993), political and economic discrepancies, poverty, discrimination, and a historical loss of autonomy may contribute to the politicization of ethnicity between minority and majority ethnic groups, which could lead to conflicts. In other words, concrete forms of deprivation, which are frequently perceived through ethnicity lens, contribute to the overall construction and politicization of ethnic identities and ethno-political conflicts. Conflicts are bound to occur in situations where one ethnic group desire to assert its authority over others (Kaldor, 1999; Turton, 1997; Huntington, 1996). Also, prevalence of intra-ethnic groups and the absence of inter-ethnic institutions increase the likelihood that riots would occur (Varshney 2002). Others think that the recurrence of conflict in ethnically divided societies is due largely to weak political institutions and the nature of the structure of electoral incentives such as entrenched patronage and WinnerTakes-All politics (Horowitz 1995; Akwetey 1996). According to Kaplan (1993), in ethnic, cultural and sectarian diversity areas where "ancient hatreds" are rife, inter-ethnic relationships reflect non-rational sentiments, which often foster powerful emotional attachments to individual identities and possible eruption of civil wars (Woodward, 1995). 


\section{Method of the study}

Using concurrent mixed methods, one-fifty closed ended questionnaires were administered to respondents chosen through the simple random sampling method from Kpandai (a typical Nawuri area) and East Gonja District (a Gonja area) in the Northern region (see Appendix 1). The two communities, Kpandai and Salaga were chosen via the purposive method because of their central place in the conflicts under investigation. Kpandia and Salaga represent Nawuri and Gonja divide respectively. The two areas were the epicenters of the ethnic conflicts. They are the traditional seats of chiefs and elders of West Gonja and East Gonja District Assemblies. Decisions by the traditional authorities have the potential of sparking ethnic conflicts in the area. Additional fifty respondents comprising ten traditional authorities (five each from Nawuri and Gonja traditional areas), twelve government officials, six non-governmental officials and twelve ordinary citizens (teachers, farmers and housewives) in the area were chosen by the purposive method for face-to-face interviews because of their peculiar insight with regard to the conflicts. Questions posed to respondents covered broad and specific areas of the conflicts such as the factors that led to the outbreak of the wars, the actors and interests involved and the cumulative effects of the conflicts on socio-economic lives of the people, among others. Data collected through questionnaire and interviews were subjected to rigorous content and thematic analysis based on central question that seeks to interrogate the extent to which the ethnic conflicts between the two dominant groups have impacted the lives of the people and the community, i.e., East Gonja and West Gonja Districts which served as the focal points of the conflicts generally (see Appendix 1).

\section{Demographic Complexion of the Northern Region}

The Northern Region is one of the ten administrative and political divisions of Ghana. It is the largest and most sparsely populated region of Ghana, which covers 70,384 km in terms of land mass and a total population of 2, 479,461, which comprise 1,249,574 females 1,229,887 males (Ghana Statistical Service, 2010). It shares boundaries with Upper East and Upper West regions to the north, Brong Ahafo and Volta regions to the south, Togo to the east, and Côte d'Ivoire to the west. The land is mostly low lying except in the north-eastern corner with the Gambaga escarpment and along the western corridor (Ghana Statistical Service 2010). 
There are 37 distinct languages in the region spoken by approximately 17 ethnic groups (Pul, 2003) that perceive themselves as indigenous (Johnsson 2007). Among the Mole-Dagbon (the principal ethnic group in the Region), Dagomba and Mamprusi are the largest subgroups, and Kokomba, Basaari and Bimoba are the largest of the Gurma group. Also, there are small groups such as Chokosi that are linked to Akan, and Gonja and Chumburu of Guan identity. The predominant languages spoken in the region are Dagbani, Gonja and Mampruli. Others are Likpakpa, Chokosi, Basaare, Kantosi, Moar, Chamba and Chumburu. The Mole-Dagbon group that is spread across 11 of the 20 districts constitute 52.7 percent of the population and the Gurmas who are concentrated in Kpandai, Nanumba, Zabzugu-Tatale, Saboba and BunkpuruguYunyoo districts, make up 27.3 percent of the population. Four districts, namely Bole, West Gonja, Central Gonja and East Gonja form the Guan ethnic group while two ethnic groups, largely migrants from southern Ghana namely Akan (3.7\%) and Ewe (1.7\%) are found in Chereponi and East Gonja respectively (Ghana Statistical Service 2010).

The Region is divided into 22 administrative districts (see Table1). Tamale Metropolitan Assembly is the most populous district in the region with a population of 371,351 . Tamale is the political, administrative and commercial capital of the region. Yendi Municipality is second largest in terms of population $(199,592)$. The least populous districts are Chereponi $(53,394)$ and Saboba $(65,706)$ (see Table 1). Generally, however, with the exception of Tamale, the Northern Region is predominantly rural in relation to other regions. For instance, Tolon Kumbungu, Saboba, Salaga and Kpandai have very high rural populations. Hence, majority of people in the region are engaged in agriculture activities such as yam, maize, millet, guinea corn, rice, groundnuts, beans, soya beans and cowpea cultivation (Ghana Statistical Service 2010). 
Table 1: Districts in the Region and Number of Inhabitants

\begin{tabular}{|l|l|}
\hline District & Population \\
\hline Bole & 61,593 \\
\hline Sawla-Tuna-Kalba & 99,863 \\
\hline West Gonja & 84,727 \\
\hline Central Gonja & 87,877 \\
\hline East Gonja & 135,450 \\
\hline Kpandai & 108,816 \\
\hline Nanumba North & 141,584 \\
\hline Zabzugu Tatale & 123,854 \\
\hline Yendi Municipal & 199,592 \\
\hline Tamale Metropolis & 371,351 \\
\hline Tolon Kumbungu & 112,331 \\
\hline Savelugu Nanton & 139,283 \\
\hline Karaga & 77,706 \\
\hline Gushiegu & 111,259 \\
\hline Saboba & 65,706 \\
\hline Chereponi & 53,394 \\
\hline Bunkpurugu-Yunyoo & 122,591 \\
\hline Mamprusi East & 121,009 \\
\hline Mamprusi West & 168,011 \\
\hline
\end{tabular}

Source: Compiled from 2010 Population Census (Ghana Statistical Service, 2010)

There are four paramountcies in the region, namely Dagbon Traditional Area whose overlord is Ya-Na, Mamprugu Traditional Area with Nayiri of Nalerigu as its head, Nanung Traditional Area is presided over by Bimbilla Naa, and Gonja Traditional Area is under Yagbonwura. Chiefs in these areas ascend to their skins (thrones) by a "gate" system (a branch of the royal family) Kaye \& Béland, 2009). In consultation with the king-makers and Councils of Elders, the Paramount Chiefs often "en-skin" sub-chiefs in sub-divisional areas under their jurisdiction and saddle them with responsibilities of payment of traditional allegiances to them (Ghana Statistical Service 2010).

The two ethnic groups that engaged in one of the fiercest conflicts in modern Ghana, the Nawuris and Gonjas are found in the Northern region of the country. Geographically, they belong to the savanna belt where the effect of climate change has left grass in places of trees because they have been harvested for timber from the $19^{\text {th }}$ century (Personal Communication, Assemblyman, Kpandai 2016). Linguistically, the Nawuris and Gonjas are Guans whose dialects are interconnected even though Mbowura (2014) has argued that the Nawuri language is close to 
the Krachi, Nchumuru and the Achode than Gonja. The ancestors of these ethnic groups did not only cultivate the same land together but also became political allies following the exchanges of diplomatic missions between the chiefs of the Nawuri and the Gonja in the late $16^{\text {th }}$ century (Interview, Chief, Salaga, 2016). They also became trade partners when Salaga became the lucrative slave market in Ghana between the $16^{\text {th }}$ and $18^{\text {th }}$ centuries. These trade and linguistic affinities stimulated communal bond and a sense of neighborliness between the two groups. This relationship buttress the perception of friendliness among tribes from Northern Ghana by their fellow tribes in the South, particularly the Ashantis who tend to refer to people from the North as "intaafo" meaning "twins" to depict the inseparable bond between them (Personal Communication, Chief, Salaga, 2015). In spite of this perceived bond, they have engaged in several conflicts mainly over land, identity and traditional power (Brukum, 2001; Kendie, 2010). Given that traditional rulers are at the center of the groups' socio-economic development aspirations in the localities, problems inherent and/or associated with chieftaincy tend to affect the development abilities, peace and security of the people in the traditional areas. Although the central concern of this paper is the assessment of the repercussions of the Nawuri and Gonja conflict on the socio-economic lives of the people and the communities, it may be necessary to establish the historical, cultural and social dynamics of the people in order to appreciate the growing incidents of conflicts among the diverse ethnic groups.

\section{The precursors to the Nawuri-Gonja Conflicts}

An array of scholarly discourses on the traditions and customs of the people in the Northern Region have noted that long before the fifteenth century, the area was inhabited by noncentralized groups such as Konkomba (Pul 2003; Ladouceur 1979; Rattray 1932). During this period, political configurations were relatively independent from one another and the relations among the people were characterized by 'mobility, overlapping networks, multiple group membership and the context-dependent drawing of boundaries' (Lentz 2000, 107).

However, by mid-seventeenth century, the Northern Region had been overrun by 'centralised' or 'cephalous' groups such as Tohajie (Dagomba, Nanumba, and Mamprusi) and Gonja under the astute leadership of Ndewura Jakpa who introduced a new culture of dynasty (Pul 2003). 
The visitors or "invaders" used aggression to subjugate the indigenous people. For instance, Dagomba troops that attacked currently western Dagomba slaughtered and exiled several tindamba (Staniland 1975). Hence, nomenclatures such as 'autochthonous' or 'indigenous' groups, 'invaders', 'foreigners' and 'acephalous' that are used in reference to land claims, ownership and sovereignty, have evinced emotions, hatred and therefore conflict outbursts. For instance, the so-called minority groups have always used cultural marginalization as basis for fighting for social status.

When the British introduced indirect rule, the colonial government imposed dichotomous relations between 'acephalous' and 'cephalous' communities, which formally established structured inequalities in the Northern Region (Kirby 2003). The belief by Imperial Britain that modernization of Northern Ghana could be achieved by formalizing chiefly kingdoms in terms of realignments of settlements, intensified dissent and internal explosions between divisional chiefs and partly conquered groups, thereby inflaming passions and warfare. In other words, the colonial administration's attempt to channel cultural evolution through selective reinterpretation and politicization of issues have led to contestations of indigenous inhabitants' claim to the land by other groups and demands for representation in chiefly structures (Skalık 1987). For instance, the subjugation of the 'non-centralized' societies under the authority of 'politically legitimate' chiefly ethnic groups was facilitated by British colonial policy of supporting the 'centralized' societies because their authority satisfied Imperial definitions of 'tribe and chieftaincy' (Talton 2010, 12). On the basis of British discriminatory policy, the colonial powers perceived Konkomba as subordinate group, and Dagomba chiefs became intermediaries between the colonial administration and the interests of the subordinate Konkomba (Kaye \& Béland, 2009). As a Nawuri chief explained, 'the Nawuris lost their sovereignty to Gonja due to the inability of the people at the time to be allowed recognition and though Nawuri resisted absorption into Gonja rule, the establishment disallowed it' (interview, Chief, Kpandai, 2016).

Furthermore, in order to assert political and traditional influence over other groups, 'acephalous' ethnic groups are often referred to as 'minority' while chiefly groups are addressed as 'majority'. These stereotypes, according to Brukum (2001:13), are regarded as derogatory because they seek 
to distinguish between 'ethnic groups that built or did not build empires in the past'. For instance, Konkomba that are numerically larger than any of the other three chiefly groups (Nanumba, Gonja and Mamprusi are known as 'minority' while Dagomba, the largest chiefly group is warmly referred to as majority. Yet, for instance when the Nanumba-Konkomba war broke out in 1981, the tensions of which carried over into the 1994 conflict, Nanumbas were outnumbered three to one and completely overwhelmed by the surrounding Konkomba 'minority'(Skalík, 1986).

\section{The outbreak of the conflicts}

The strict compartmentalization of the Northern fiefdoms into minority and majority groups, in which ethnic groups are frequently defined as two blocks, have elicited conflict and violence among the competing forces such as Nawuri and Gonja. As one Gonja intellectual rightly noted, 'it was the same land right issue, which resulted in the mutual attacks between Nawuri and Gonja from 1991-1992' (Personal Communication, Abdulai Sani, 2016). The resultant bloody stalemate could only be broken by the state military intervention (Jonsson 2007:9). Indeed, from the 1980s Nawuri and Gonja have lived as archrivals to the extent that they would join likeminded groups in alliances against the other. For instance, in the Kokomba-Nanumba war of 1994, 'non-chiefly' Nawuri, in a pact with Nchumburu and Bassare fought alongside Konkombas against the 'chiefly' group, Nanumba who also received friendly support from co-chiefly groups such as Dagombas and Gonjas.

Respondents identified several interrelated factors that precipitated the Nawuri-Gonja war of 1991. A first incident, which occurred in April 1991 was 'the mob attack which led to the death of a Nawuri in a predominantly Gonja town of Salaga' (interview, Alhaj Musa, Kpandai, 2016). Gonja forces extended their ferocious attacks on all Nawuris and chased them out of Kpandai and its environs. However, in June 1991, the Nawuris regrouped, returned to Kpandai and gave warning by marking non-Gonjas and non-Nawuris compounds and houses with green leaves to distinguish them from the target groups (interview, Karim Sidiq, Kpandai, 2016). The fierce clashes led to the death of nine (9) Nawuris, one (1) Basare man and ten (10) Gonjas but the latter fled from the area (interview, Salifu, Kpandai, 2016). 
Of the casualties, the Basare was regarded as extremely catastrophic because of the fear that the neighboring kokombas who are closely related to the Basares could be drawn into the conflict. In order to avert a backlash from Kokombas, the Gonjas appealed to the Nanumba chief of Bimbila to negotiate with the Kokomba, and rendered traditional apology for the death of the Basare youth, which was never accepted (The Mirror, 1991: 7).

The conflict was resurrected in May 1992 when 30 well armed Gonjas accompanying a new chief to Kpandai invaded farmlands, harvested crops and looted animals from the market and in the process killed a Kokomba storekeeper. The Nawuri youths responded with a strong force by attacking and destroying a petrol station, which killed the owner who happened to be a Gonja. The chain reaction was disastrous. The non-chiefly verses chiefly groups entered into war pacts and fought one of the brutal ethnic wars in the Northern Region. Thus, the Nawuris-KokombaNchmuru- Basare alliance on one hand against Gonja-Nanumba-Dagombas forces, on the other. In the process, the Nawuri-allied forces overpowered and massacred Gonjas, mutilated their bodies and beheaded the chief and confiscated their weapons. Two vehicles carrying Gonja warriors to Kpandai were ambushed and killed all the passengers. Also, some of the major Gonja towns were looted and houses were burnt, in which thousands of displaced persons sought refuge at Tamale. At Kpembe the village chief who was also the father of the then Northern Regional Minister and 12 members of his household and houses were utterly destroyed (Drucker-Brown, 1995). With support from Nawuri allies, they pursued Gonjas who had sought refuge at Kpandai Police Station and massacred them as the police looked on helpless (Ampiah 1991). The Gonja accuse the police for acting unprofessionally (interview, Chief, Salaga 2016). The Nawuris also charged that none of the Gonja mob that killed the Nawuri youth at Salaga had been punished. According to the Nawuris, it was difficult to obtain justice in a situation where the murderers had escaped punishment because 'the Regional Minister who is the son of a Gonja chief had concealed the truth by shielding his people who perpetrated the criminal act' (Personal Communication, Mohammed Soglo, 2016). 
After the war skirmishes abated in early 1992, tension continued to mount between the two contrasting groups. The situation was made virulent by the lack of effective and efficient peace process for resolution the conflict even though the Justice Ampiah Committee had been set up to settle the conflict (interview, Ibrahim, Gombe, 2016). According to Malam Adongo, 'the unresolved conflict and mounting tensions due to politicization of the ethnic issues contributed to the reoccurrence of another bloody war between the two forces in 1994. One account given by some elders of Kpandai contends that the conflict was directly related to issues of chiefly power. Majority of respondents 87 percent explained that 'the tension that had existed between the two opposing groups (Nawuri and Gonjas) was aggravated by competition between Gonja Youth Association and Nawuri Youth Association' (interview, respondents, 2015). The Nawuri Youth Association was provoked by Gonja Youth Association's decision to hold its annual meeting in Kpandai, a town Nawuris claim as their ancestral capital. Meanwhile, Gonjas regard the same town as one of its chiefly traditional enclaves and hold it under the jurisdiction of Yagbumwura the head of Gonja Traditional Council (interview, Salisu, 2016). The Nawuri chief viewed the decision for the meeting of Gonja Youth Association as a direct assault on his authority and appealed to the government to prevent the meeting. The Nawuri chief castigated the Yagbumwura for pushing for an agenda that amounted to a gross disrespect for Nawuri people's usufruct right to their homeland (interview, Abanga, Kpandai 2016). By April 1994, it had become apparent that the intransigent positions taken by Nawuris and Gonjas on the status of Kpandai had proven to be difficult to be resolved by any third party (Talton, 2010: 169). Between mid-April and late June, Kpandai and its environs were burnt and looted in two separate clashes between Gonjas and Nawuris. As one senior government official at Kpandai rightly noted, 'like all conflicts in Northern Region, Nawuri-Gonja 1994 conflict occurred largely around competing claims to land rights, in which members of the chiefly group were confronted by peoples they regard as subjects' (Personal Communication, Dauda Mohammed, 2016). For instance, while Nawuri claim autochthonous origins near the market town of Kpandai, Gonjas, that are numerically and politically dominant minority within a large ethnically heterogeneous area, and ascribe descent to the invading founders of the kingdom, also lay claim to the town because the Yagbumwura regard Nawuris as subjects (Personal Communication, Official of Gonja West District Assembly, 2016). 
It is evident from interactions with respondents that one underlying issue, was land rights and marginalization. Hence, for Nawuris, 'the war was fought on account of self-emancipation' (interview, Nuruden Musa, 2016). For instance, when asked to indicate the causes of the conflicts, 62.2 percent said they revolved around land disputes. In contrast to a minority (37 percent) who contended that Kpandai was conquered by the legend Ndewura Jakpa, 56 percent disagreed. As 85 percent of respondents rightly explained, 'the wars between the two ethnic groups have been largely about the struggle over who has the right to allocate land for farming and commercial activities in Kpandai area' (Interview, Nawuris and Gonjas Youths, 2015). Hence, in the opinion of 61 percent of respondents, 'the conflicts have broken out because of attempts by Gonjas to deprive Nawuris of the use of their own lands' (interview, respondents, 2015). The same opinion was expressed by the Chief Police Officer in the district, 'it is the attempt by one group to claim ownership of the traditional lands, which the other regards as a usurpation of traditional inheritance by the other group' (Personal Communication, Kpandai, 2016). As 43 percent rightly noted, disagreement over the institution of the "Kanankulaiwura" in Kpandai and in other Nawuri settlements such as Bladjai by the Gonja chief infuriated the Nawuris, thereby fuelling the conflict. The Nawuris maintained that "the "kanankulaiwura" was an imposition by Gonja settlers on their land in the late $17^{\text {th }}$ century, which was consolidated in the 1930s at the peak of the British colonial policy of indirect rule' (Personal Communication, Nawuri Youth Leader, Kpandai 2016).

To this political division a religious one has been added. Catholic missionaries have long converted Nawuris into Christianity while Gonjas, though not generally Muslim, regard themselves as closer to Islam than Christianity. The Nawuris believe that the outbreak of the fighting in Kpandai in 1994 was facilitated by Gonja anti-Christian actions, in which a Gonja chief threatened to sell a piece of land on which the Roman Catholic Church is built. Gonjas accused the Catholic priest in the area for religious indoctrination of Nawuris. As one Gonja chief intimated, 'the Christian pastor was involved in liberation theology, which was interpreted by my people as a kind of instigation of the subjects to protect their inalienable rights to their homeland - by rising up against their 'oppressors' (Personal Communication, Kpandai, 2016). 
However, only a minority of respondents, 12 percent of the respondents said the conflict emanated from religious differences.

\section{Ramifications of the Wars}

Conflicts are detestable because they leave behind damages that sometimes are irreparable. A major concern among policy-makers and students of conflicts in Africa, in particular is with regard to the 'soft African state' which has proven incapable of structuring society in a manner to contain ethnic conflicts once they have occurred. As is the case with Nawuri-Gonja wars, which largely occurred around chiefly pedigree, first-comers' rights, autochthony, historical rights and injustices, the unresolved issues have led to grave consequences for the people and society (Personal Communication, Chief, 2015). Whereas conflict theorists have grappled with how to evaluate ethnic conflicts on society, in much of Africa as elsewhere, the collective cost of conflicts on populations and other material resources that provide foundational livelihoods to the people, have been the dominant method.

\section{Human, Social and Economic Loses}

While it is always difficult to make an accurate calculations about the financial cost of conflicts in Africa, postmortem evaluation of losses from Nawuri-Gonja wars in monetary terms has been estimated to be a whooping six hundred thousand Ghana Cedis (GH 600,000.00), the equivalent of three hundred thousand dollars $(\$ 300,000)$ using the 1994 exchange rate (Interview, Regional Finance Officer, Tamale, 2016). When viewed in comparative terms, the amount may look insignificant, however, considering the fact that East Gonja and West Gonja District Assemblies are among the poorest of the poor districts in Ghana, any little amount spent on wars could have fixed many social services for the transformation of livelihoods of the people. According to a respondent, 'the loss of human lives and property has been a major concern of not only the Government of Ghana but chiefs and their peoples' (Personal Communication, Mahmoud Iddris, 2016). Hence, according to 78 percent of respondents, 'hundreds of people who lost their lives and thousands of them that lost their valuable possessions and several hundreds who were rendered homeless constituted a national catastrophe'. According to Baba Musah, an opinion leader (interview, Kpandai, 2016), 'there were instances where as many as 56 families lost all 
property to arson'. The 'burning of houses and other properties by warriors of the two groups plunged many peasantries into severe economic crisis'. In response to the question of how the war affected the economic lives of the people, 87 percent mentioned 'loss of daily incomes, houses and personal property'. The burning of houses as a means of decapitating opponents led to internal displacement of people. As some respondents rightly mentioned, 'for several weeks, the displaced were stranded in the April-May early rains thereby aggravating their bad conditions' (interview, Mallam Yahaya and Daniel Imoro, Salaga, 2016). A farmer recounted how she lost her 'cloths in an enemy arson and looting' (Personal Communication, Salifu Agnes, Kpandai, 2016). A cumulative loss of personal valuables gathered from 20 families was estimated to have cost seven thousand US dollars $(\$ 7,000.00)$. According to a senior member of the royal family at Salaga, 'none of the families who lost property has been able to recover from the financial shocks they suffered from the wars' (interview, Mallam Sahanuon, 2016).

The preoccupation of the Nawuris and Gonjas that battled for supremacy over land and chiefly rights are farming, animal husbandry, fishing and hunting (Interview, Officer of Gonja West District Assembly, 2016). As 92 percent of the respondents rightly pointed out, 'apart from a few small scale agro-based farming industrial activities largely located in the district capitals of Kpandai and Salaga, the people live on subsistence agriculture'. Given that agriculture is the main occupation of the people, 'when the conflicts obstructed the people's ability to undertake farming activities, they faced starvation and loss of incomes' (interview, Lucy Bio, Kpandai, 2016). Also, an overwhelming 98 percent of respondents admitted, experiencing a total destruction of their farming businesses. Putting it more succinctly, a 54 year old mother of six said, 'the conflicts brought about a complete halt to our agricultural activities in the area' (interview, Grace Abanga, Salaga, 2016). The general destruction to the people's agricultural activities implied severe shortages of food items when the conflicts abated and life returned to a normalcy. As some respondents rightly noted, 'the protracted conflicts prevented us from cultivating new crops throughout the farming seasons' (interview, Suley and Bissau, Kpandai, 2016). Three police officers who observed the war corroborated the claim made by the respondents, 'the guerilla nature of the war scared the farmers from going to the fields' (interview, police officers, Kpandai, 2015). 
According to a female Nurse at the Kpandai Government Hospital, 'armed bandits' attacks on women who attempted to engage in planting of their crops brought a virtual halt to farming activities in this area' (Mary Fati, Kpndai, 2016). A majority of the respondents, 96 percent indicated that, 'farm materials we had purchased for planting were left to rot due to the protracted war'. Interestingly, 78 percent of the farmers said they had started ploughing their farmlands for crop cultivation when the 1994 conflict broke out thereby leading to the abandonment of the field activities. This is because in many cases, 'the farmlands were also the battlefields' (Personal Communication, Civil Servant, 2016). Indeed, according to a 63 year old farmer, 'a major war strategy of the combatants involved the destruction of farmlands of opponents in order to force them to surrender' (Personal Communication, Ibrahim Salifu, Salaga, 2015). Furthermore, a Nawuri combatant confirmed that, 'the warriors fed on the spoils of crops from opponents' farms thereby causing imminent faming albeit temporary' (Personal Communication, Abukari Usman, Kpandai, 2015).

Already lagging behind in social and economic infrastructure, the protracted conflicts aggravated the debilitating poor physical infrastructure in the East Gonja and West Gonja districts. According to some officials of the district assemblies, a total of 40 percent of the rural roads in the area was utterly destroyed due to the conflicts. Also, more than two-thirds of respondents acquiesced to the question that, 'the problem of infrastructure accessibility in the area was worsened by the wars'. The insecurity in the area, which prevented District Assemblies and Ministry of Roads officials from undertaking regular maintenance left much of the road networks in a bad state thereby cutting off some of the rural areas from the district centers (interview, Samuel Okoh, 2016). More than two thirds of respondents, 79 percent said, the conflicts caused severe damages to school buildings, health centers and private homes. Specifically, seventy-six (76) percent of respondents said school infrastructure was destroyed in large proportions while 84 percent mentioned that healthcare facilities constructed with local materials were burnt down. Asked whether people could access health centres during the conflict periods, 81 percent said they could not access the clinics, 69.4 percent also said, the medical staff run away from the conflict areas, and 74.2 percent indicated that some of the health centers were abandoned and left in the mercy of the rains and strong winds, until they were destroyed. 
Indeed, a larger proportion of the respondents (96 percent) agreed to our question that, 'it was not possible for us to access health facilities at the time of the conflicts'. Market centres were not left out in the mass destructions. According to a key respondent, 'over 17 community market centers that had been constructed with local materials were easy destroyed during the conflicts'. For instance, in Kpandai and the neighboring villages, the epicenter of the ethnic war, several houses made of mud and grass roof were burnt to ashes (Daily Graphic 1992; The Chronicle 1994).

\section{Damages Caused to Education}

The effect of the conflicts on education was one of the saddest in the narrative. Yet, among the districts in the country, East Gonja and West Gonja are among the severely deprived in educational infrastructure, teacher-pupil ratio and lowest in quality (Personal Communication, GES Officer, Salaga, 2016). According to 86 percent of respondents, the protracted NawuriGonja wars caused severe destructions to some of the elementary school buildings most of which were already in a deplorable stage. Mostly built with 'local materials such as bamboos, long grasses, woods and mud, a number of school buildings in the conflicts areas were utterly destroyed by the warriors' (Interview, Assemblyman, Salaga, 2016). According to an official of Ghana Education Service (GES), 'a total of 23 elementary school buildings were destroyed by the conflicts' (Personal Communication, Kpandai, 2016). A finance official of East Gonja District Assemble disclosed that the cost of destruction of schools infrastructure (books, buildings and other teaching aid) amounted to over ten thousand US dollars $(\$ 10,000)$.

Already suffering from a shortage of professional teachers, the war, which displaced hundreds of the teachers, worsened the educational problem. According to a GES official, 'the war did not only disperse the teachers across the Northern Region but also encouraged their mass transfers from the conflicts areas' (Personal Communication, John Twum, Salaga, 2016). Traumatized by the carnage, young teachers, particularly women appealed for voluntary transfers from the war zone. As more than two-thirds (81 percent) of respondents indicated, the protracted war forced the young teachers to opt for reposting to safety communities leaving the conflicts areas without teachers. 
The Education Service Directorate at Tamale confirmed the fact that, since the conflicts broke out, many young teachers have resisted postings to the "war endemic" areas of East Gonja and West Gonja District' (Personal Communication, GES Officer, 2016). The mass migration of teachers from the conflicts zone led to temporary closures of schools. This is because according to one of the Assembly members of East Gonja District Assembly, 'school-children were disturbed by the internal displacements due to the lost of properties and homes of their parents' Abdul Sinare, 2016). Furthermore, families' separations due to the conflicts affected school pupils' progression to the next levels of their education. Pupils who had been preparing for the national examinations to enter senior high schools, were caught up in the middle of the conflicts, thereby bringing to an abrupt suspension, their education career. Two teachers who were affected by the conflicts explained, 'after the conflicts, the population of pupils in the schools dropped to record low by 14 percent' (interview, Yeboah, Martin and Mohammed, Kpandai 2016). Responding to our question on the social effects of the wars, a senior health official at the East Gonja District Assembly summed it all, 'the period brought agony to parents, teachers, pupils, health professionals, and the losses were incalculable' (Cynthia, Osei, Kpandai, 2016).

\section{Deprivation suffered by women and children}

Experiences from civil wars in several African countries indicate that the vulnerable groups such as women and children are always at the receiving ends whenever conflicts occur. Not surprisingly, majority of the respondents, 86 percent said, women and children were the most affected by the war catastrophes. Hospital officials recounted the outbreak of cholera during the raining reason, dehydration during the severe summer period, leading to infant and children mortality even though they could not indicate the actual deaths resulting from the tragedy (Personal Communication, Agnes Okyere, 2015). Hospital officials at both Kpandai and Salaga District Hospitals said, 'there were high rates of reported cases of children who suffered from malaria, fever and common infections during the periods of the conflicts'. Compounding the health concerns of the children was the nutritional deficiencies. According to 65 percent of respondents of which half were women, food insecurity caused change in regular diets of the children, which triggered malnourishments in their health conditions. Furthermore, it was reported by 95 percent that children suffered hunger for several months, and some died out of 
malnourishment related diseases. According to a clinical psychologist at the Kpandai hospitals, 'the deteriorated health of the children caused panic and emotional trauma to their parents, particularly, the mothers' (Personal Communication, Alice Narh, Kpandai 2016). A minority of respondents (36 percent) reported cases such as rape, pregnancy complications and infectious diseases suffered by lactating mothers. The escalated health problems, according to some respondents, were the result of the 'lack of access to hospitals by pregnant women and lactating mothers due to fear of reprisals from warriors of opponents' (interview, Zinabu, Adamu and Musa, 2016). So too did antenatal visits plummet. When asked to indicate why the women stopped visiting the hospitals during the conflicts period, an overwhelming 87.4 percent mentioned the fear of being raped, robbed and killed by armed bandits. A local chief informed the researchers that two pregnant women lost their lives during labor and two pupils (girls) died when poisonous snakes attacked them (Personal Communication, Chief, 2015). It was reported that some of the young girls dropped out from school due to pregnancy and early marriages. According to some respondents, 'parents rushed their young school-going girls into marriages in order to guarantee their physical security by the able-bodied men (interview, Mary Abugri, 2015). To-date, East-Gonja and West-Gonja districts remain in the quagmire of poverty, having alienated themselves because of many years of ethnic conflicts (Personal Communication, District development Officer, 2016).

\section{Conclusion and Lessons}

This paper has examined the complex dynamics of conflicts in Ghana's Northern Region with particular emphasis on Nawuri-Gonja conflicts. It has highlighted several imperatives that have shaped occurrences of ethnic conflicts among the neighbouring groups. The discussions have revealed that the Nawuri-Gonja conflicts have their roots in history, tradition, and custom that have converged with modern provisions of rights and emancipation from servitude. As long as society continue to endorse traditional stereotypes such as minorities and majorities and institutionalized their applications ethnic conflicts would not die down. These lingering pertinent issues have always been exploited by factionalists groups to foment troubles even at the least provocation. Although causes and processes of conflicts matter, one must note that contemporary conflicts in Ghana such as the Nawuri-Gonja wars generated differing degrees of impacts 
involving psychological, economic, social, health and human catastrophes. Therefore, in these kinds of conflicts, counting the cost has a greater value than any other measurement. As already shown in the discussion, the communities where the two ethnic groups fought their wars have sunk into deterioration and the hope of recovery is slimmer than had been anticipated. Against this backdrop, the study proffers salient lessons to be learnt for future conflict situations.

First, unbridled exploitation of ethnic identity by groups in their quest for land and resources is the underlying incentives for the many post-Cold War inter-ethnic conflicts in Ghana. The growing incidents of conflicts in Ghana as evident in the Nawuri-Gonja wars is gripped by ethnic "nationalism" dramatized by attempt to subjugate so-called non-chiefly minorities by chiefly majority. These parochial divisions are responsible for the simmering ethnic tensions in the Northern Region. Second, understanding group violence conflicts is often mirrored by social psychology in which discourses of ethnic discrimination whether generalized and homogenized discontent within a group, provide plausible explanatory factors for understanding frequent occurrences of conflict, in which perceived insults and disrespectful behaviour, can be inserted and translated into threats to individual and group status to justify conflict. Third, the synergy between development and conflict exists on different practical levels. Thus, conflict is development in reverse in which socio-economic damages grievances they perceive as important in the causation of the violence, and of course through the effects of the fighting. Conflict has not only disrupted the progress of this region, destroying its resources and development projects, but the tensions underlying it are intertwined with many other issues, political and traditional. 


\section{Reference}

Akwetey, E. (1996). Ghana: Violent ethno-political conflicts and the democratic challenge'. In A. O. Olukoshi \& L. Laakso, (Eds.), Challenges to the Nation-State in Africa. Uppsala: Nordic African Institute, 102-135.

Ampiah, J. (1991). Report of the Committee of Inquiry into the Gonjas, Nawuris and Nanjuro Dispute. Accra. Assembly Press.

Assefa, H. (2001). Coexistence and reconciliation in the northern region of Ghana. In Reconciliation, justice, and co-existence (Ed.), M. Abu-Nimer, 165-86. Lanham: Lexington Books.

Awedoba, A. K. (2009). An Ethnographic Study of Northern Ghanaian Conflicts: Towards A Sustainable Peace. Accra:Sub-Saharan Publishers.

Bakwesegha, C. (2004). Ethnic conflict and the colonial legacy. In: Facing ethnic conflicts (Ed.), A. Wimmer et al., 53-60. Lanham: Rowman and Littlefield. Sub-Saharan Publishers.

Berger, P., and T. Luckmann. (1967). The social construction of reality. New York, NY: Anchor.

Brukum, N. J. K. (1999). Chiefs, Colonial Policy and Politics in Northern Ghana, 1897-1956.

Transactions of the Historical Society of Ghana 3: 101-122.

Brukum, N.J.K. (2001). The Guinea Fowl, Mango and Pito Wars: Episodes in the History of Northern Ghana, 1980 - 1999. Accra: Ghana Universities Press.

Crawford, B. (2007). Globalization and Cultural Conflict: An Institutional Approach. In H. Anheier and Y. R. Isar (Eds.) The Cultures and Globalization Series: Conflicts and Tensions, 3150, Thousand Oaks, CA: Sage. 
Daily Graphic. (1992). June, P. 1.

Drucker-Brown, Susuan. (1995). Communal Violence in Northern Ghana: Unaccepted Warfare. In: Hinde, Robert, A., and Watson, Helen, E. (Eds.). War: A cruel Necessity?: The Bases of Institutionalized Violence. London \& NY: I.B. Tauris Publishers, 37 - 53.

Eriksen, T. (1993). Ethnicity and nationalism: Anthropological perspectives. London: Pluto Press.

Ghana Statistical Service. (2010). 2010 Population and Housing Census Summary Report of Final Results. Accra: Ghana Statistical Service.

Gurr, T., and A. Pitsch. (2003). Ethnopolitical conflict and separatist violence. In International Handbook of Violence Research (Eds.), H. Wilhelm and J. Hagan, 227-45. Dordrecht: Kluwer.

Horowitz, D. L. (2000). Ethnic groups in conflict. Berkeley: University of California Press.

Jönsson, J. (2007). The overwhelming minority: Traditional leadership and ethnic conflict in Ghana's Northern Region. Centre for Research on Inequality, Human Security and Ethnicity Working Paper No. 30, February.

Kaldor, M. (1999). New wars and old wars: Organized violence in a global era. Cambridge: Cambridge University Press.

Kaplan, R. (1993). The Balkan ghosts: A journey through history. London: Macmillan.

Kaye, Julie \& Béland, Daniel. (2009) The politics of ethnicity and post-conflict reconstruction: The case of Northern Ghana, Journal of Contemporary African Studies, 27:2, $177-200$ 
Kendie, S. B. (Ed.). (2010). Conflict management and peace building for poverty reduction, Proceedings of the 2010 Harmattan School. Tamale: CCEIR.

Kirby, J. (2003). Peace-building in Northern Ghana: Cultural themes and ethnic conflict. In Ghana's North: Research on culture, religion, and politics of societies in transition, eds. F. Kro“ger and B. Meier, 161-205. Frankfurt am Main, Germany: Peter Lang.

Ladouceur, P.A. (1979). Chiefs and Politicians: The Politics of Regionalism in Northern Ghana, London: Longman.

Lentz, C. (2000). Colonial constructions and African initiatives: The history of ethnicity in Northwestern Ghana. National Museum of Ethnography 65: 107-36.

Lentz, C. (2006). Ethnicity and the making of history in Northern Ghana. Edinburgh: Edinburgh University Press.

Lund, Christian. (2003). Bawku is still volatile: Ethno-political conflict and state recognition in Northern Ghana. The Journal of Modern African Studies 41 (4), 587-610.

Mahama, I. (2003). Ethnic conflicts in Northern Ghana. Tamale: Cyber Systems.

Mbowura, Cletus. K. (2014). Security and Conflicts: Appraising and Interrogating Security Arrangments in the Nawuri and Gonja Conflicts in Northern Ghana. International Journal of Development and Sustainability 3 (7): 1502 - 1516.

The Mirror, 6 June, (1991): 6 - 7.

Nugent, P. and C. Lentz (2000). Ethnicity in Ghana: the limits of invention. Basingstoke: St. Martin's Press. 
Pul, A. S. H. (2003). Exclusion, Association and Violence: Trends and Triggers in Northern Ghana’s Konkomba-Dagomba Wars. African Anthropologist 10 (1): 39-82.

Rattray, R. (1932). Tribes of the Ashanti Hinterland. Oxford: Clarendon.

Rothchild, D. (1997). Managing Ethnic Conflicts in Africa: Pressures and Incentives for Cooperation, Washington, D.C., Bookings Institution Press.

Skalník, P. (2002). The State and Local Ethno-political Identities: the Case of Community Conflicts in Northern Ghana. Noveaux Mondes 10: 141-166.

Skalnik, P. (1987). On the Inequality of the concept of the traditional state. Journal of Legal Pluralism and Unofficial Law 25 \& 26, 301-325.

Scott, G. (1990). A resynthesis of the primordial and circumstantial approaches to ethnic group solidarity: Towards an explanatory model. Ethnic and Racial Studies 13: 147-70.

Staniland, M. (1975). The lions of Dagbon: Political change in Northern Ghana. Cambridge: Cambridge University Press.

The Ghanaian Chronicle. (1994). War raptures economic activity in Northern Region Accra' 1, 8.

Tonah, S. (2012). The politicization of a chieftaincy conflict: The case of Dagbon, Northern Ghana. Nordic Journal of African Studies 21 (1) 1-20.

Tsikata, D., \& Seini, W. (2004). Identities, inequalities and conflicts in Ghana. Centre for Research on Inequality, Human Security and Ethnicity (CRISE), Working Paper 5, Oxford, November. 
Turton, D. (1997). War and Ethnicity: Global connections and local violence. New York: University of Rochester Press.

Talton, Benjamin, (2010). Politics of Social Change in Ghana: The Kokomba Struggle for Political Equality. New York: Palgrave Macmillan.

Talton, B. A. (2003). The Past and Present in Ghana's Ethnic Conflicts: British Colonial Policy and Konkomba Agency, 1930-1951. Journal of Asian and African Studies 30 (2-3): 192-210.

Varshney, A. (2002). Ethnic conflict and civic life: Hindus and Muslims in India. New Delhi; Oxford University Press.

Woodward, S. (1995). Balkan tragedy: Chaos and dissolution after the cold war. Washington, D.C: Brookings Institute. 


\section{Appendix 1}

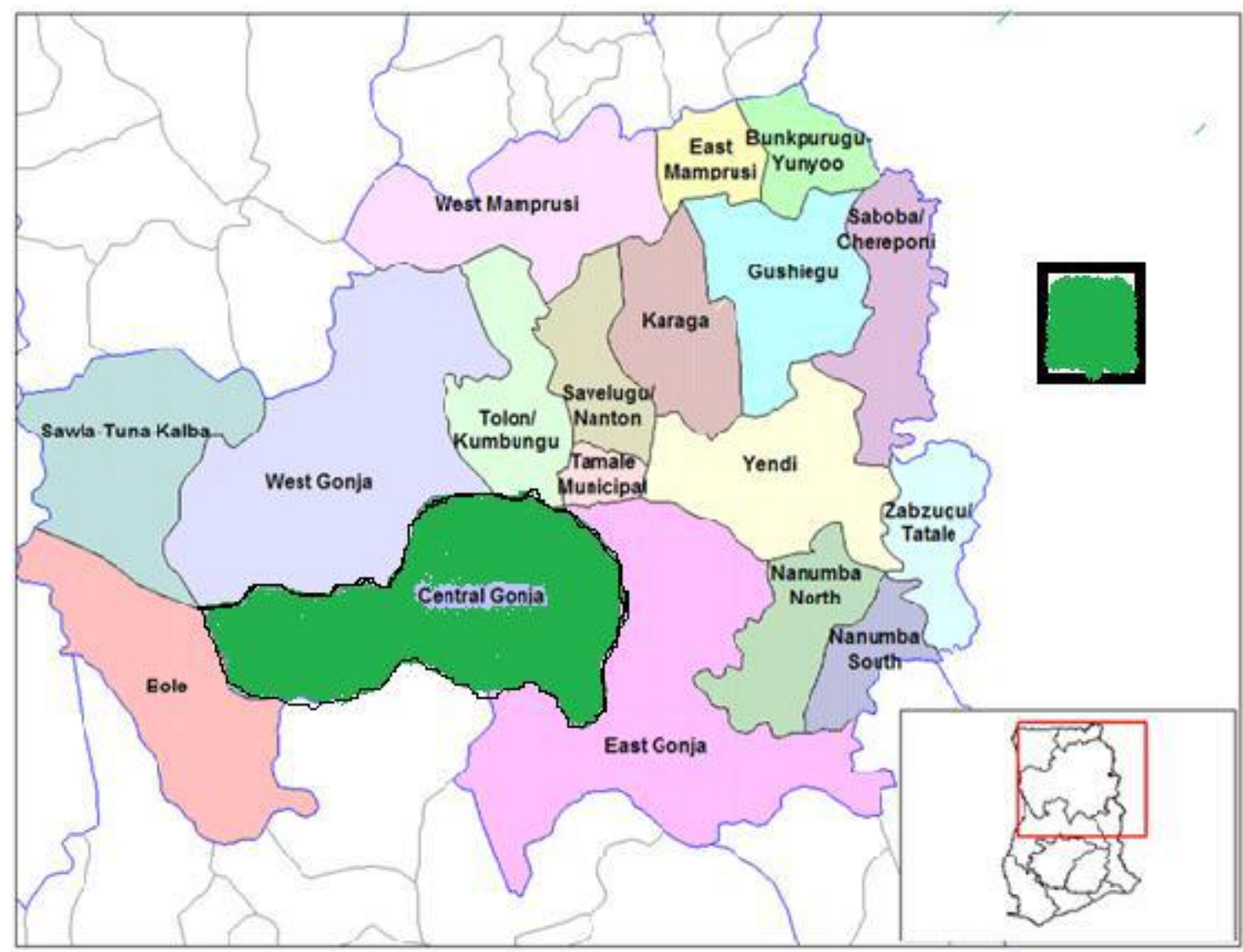

